DOI: $10.20472 / E S .2019 .8 .2 .002$

\title{
DOES PERFORMANCE BUDGETING SYSTEM AFFECT FISCAL PERFORMANCE IN OECD COUNTRIES?
}

\section{FATIH DEYNELI}

\begin{abstract}
:
Fiscal institutions tend to affect government deficit besides the macroeconomic variables. Fiscal institutions cover all rules and regulations in the budgetary process. Countries already have a standard performance budgeting framework to allocate budget resources. However, some countries don't connect performance information with budget results, which means that performance information has no effect on the budgetary result if targets are not met.

This article investigates the relationship between budget deficit and performance budgeting system (II). More specifically, our aim is to investigate the relationship between general government deficit and performance budgeting system when there are no budgetary consequences if targets are not met.

For this purpose, the 2016 OECD Performance Budgeting Survey data will be used to define the performance budgeting variables. The results show that countries which have budgetary consequences if targets are not met tend to have a lower government deficit.
\end{abstract}

\section{Keywords:}

Performance budgeting, fiscal performance, government deficit, OECD countries, performance information

JEL Classification: H61, H63

\section{Authors:}

FATIH DEYNELI, Pamukkale University, Turkey, Email: fdeyneli@pau.edu.tr

\section{Citation:}

FATIH DEYNELI (2019). Does Performance Budgeting System Affect Fiscal Performance in OECD Countries?. International Journal of Economic Sciences, Vol. VIII(2), pp. 22-34.,

10.20472/ES.2019.8.2.002 


\section{Introduction}

The economic environment composed of government expenditure, monetary policy credibility and lack of trade openness tends to affect the government deficit in terms of the macroeconomic aspect (Swamy 2015). The large body of theoretical and empirical literature has been developed to investigate the relationship between budget deficit and macroeconomic variables (Saleh and Harvie 2005).

However, the macroeconomic variables alone cannot provide satisfactory explanations for the differences between the countries because of the fact that budgetary institutions also affect the government deficit. Budgetary institutions cover all (formal and informal) rules and regulations and define the roles and responsibilities among the various actors at each stage of the budget process, which are preparation, approval, execution and control (Alesina et al. 1999; Gollwitzer et al. 2010).

Alesina and Perotti (1999) divide the fiscal institution into groups. In the first group, the fiscal institution is defined as laws that determine numerical indices about targets on budget. In the second group, the fiscal institution is defined as procedural rules. They are;

1- $\quad$ The formulation of a budget proposal within the executive body

2- $\quad$ The presentation and approval of the budget in the legislative process

3- $\quad$ The implementation of the budget by bureaucracy

Countries use a performance-based budgeting system (PBB) to regulate the budget process. PBB is a form of budgeting that relates funds allocated to measurable results (OECD 2005). It uses the procedures to strengthen links between the public sector funds and performance information (outcomes or outputs) (Robinson and Brumby 2005). The basic idea is that governments should analyse the budget for expected results (typically labelled as outputs and outcomes) rather than for inputs such as personnel, supplies and other items (Shick 2007). Academics and practitioners are still concerned about how performance information affect the budgetary process, resource allocation and fiscal performance (Moynihan and Beazley 2016; Raudla 2012). Performance-based budgeting aims at improving efficiency, effectiveness and transparency. Decreasing the budget deficits by achieving savings is also an important objective of performance-based budgeting (Curristine 2005).

Although countries have adopted performance-based budgeting as public expenditure framework, there have been different approaches. Some countries such as the United States use strategy and performance plans which include performance targets. Other countries have performance agreements which are between a minister (or ministry) and a public agency or between a public agency and a department of the agency (for example the United Kingdom) (Curristine 2005).

Furthermore, OECD divides the performance-based budgeting into three categories according to the relationship between performance information (PI) and funding: (I) presentational system, (II) performance-informed system and (III) direct/formula performance budgeting system. Performance information does not play a role in funding and decision-making process in the presentational system. PI focuses on information only for the purposes of accountability and dialogue with legislators and citizens. PI is important in the budget decision-making process but it 
does not necessarily determine the number of resources allocated in the performance-informed system. Funding is directly based on results achieved in direct/formula performance budgeting. It means that the allocation of public resources is directly and explicitly connected to the units of performance (OECD 2007).

Country experts usually characterize their systems as "the presentational system". This is one of the problems while implying the PB in the budget process because there is no clear or consistent link to the budgetary decision-making process in the presentational system. In this case, there are no budget consequences such as budget decreases, freezes and increases if targets which are defined at the beginning of the period are not achieved. Hence, both academics and practitioners are still concerned about how performance information affect the budgetary process and resource allocation (Moynihan and Beazley 2016; Raudla 2012).

Moreover, this might transform the performance-based budgeting into a paper exercise which not only has a less significant impact on budget decision making but also invalids the performance indicators for budget decisions. Many ministries of finance officials in OECD countries consider this situation. They also think that little budgetary use has been made of the performance indicators developed as part of the performance budgeting reforms and that many of these indicators are irrelevant to budget decisions (Robinson 2016). Therefore, performance-based budgeting can affect fiscal performance according to how it is implemented.

The aim of this study is (I) to investigate the relationship between government deficit and performance budgeting system in general (II) and to investigate the relationship between general government deficit and performance budgeting system when there are no budgetary consequences if targets are not met in particular.

\section{Literature Review}

Improving fiscal performance by reducing the budget deficit has been one of the main pillars of the macroeconomic policymaking. In the early 1970s, economic determinants of the fiscal policy and budget deficit were more important. After the first oil crisis in 1973, high budget deficits became a problem for many industrialized countries. Additionally, the budget deficit became prominent after the European debt crisis in 2008. It was considered that one of the fundamental reasons for the European debt crisis in 2008 was excessive budget deficit (Maltritz and Wüste 2015). However, the economic variables alone couldn't provide satisfactory explanations for the differences between deficits and debt levels for different countries. ${ }^{1}$ Therefore, the impact of the political and institutional determinants, such as the political stability, corruption, law and order, on the budget deficit has been increasing (Arif and Hussain 2018; Ifere and Okoi 2018).

There have been many theoretical and empirical studies in political economy literature that have analyzed the political and institutional determinants of fiscal policy (Arif and Hussain 2018; Roubini 1991; Roubini and Sachs 1989; Woo 2003). One group study focuses on the effect of the electoral system on the size of budget deficits among countries. In this respect, studies generally

\footnotetext{
${ }^{1}$ For instance Roubini et al. (1989) emphise that „As for budget deficits, we showed that much could be explained by normal cyclical factors (the slowdown in growth and the rise in unemployment after 1973), but that in addition, the size of the budget deficits was related to political as well as economic characteristics of the countries."
} 
use political explanatory variables to explore the determinants of the budget deficit such as the type of government (coalition, majority government or a minority government, left government), electoral system, government structure and political polarization. The second group study focuses on the effect of the budgetary institutions such as budgetary process and transparency on the budget deficit (Alesina and Perotti 1999; Hallerberg and Von Hagen 1997; Roubini and Sachs 1989). Composed of the rules and regulations according to which budgets are drafted, approved, and implemented, the budgetary process is defined as a budgetary institution (Alesina and Perotti 1996).

Von Hagen (1992), who provides the first comprehensive empirical analysis, uses budgeting procedures as a political and institutional variable to investigate the role of these procedures in terms of fiscal performance. He argues that institutional reform of the budgeting process may be a promising alternative for the European Communities to foster fiscal stability. Budgetary procedures are divided into three levels: bargaining within the cabinet of ministers, passing of the budget law through parliament, and the execution of the budget.

He argues that government, parliament, finance ministers and central budget authority have different roles and responsibilities during the budgetary process. Hence, his structural hypothesis focuses on the "structure of negotiations and decision-making procedures during the budgeting process and the execution of the budget law". He concludes that when a budgeting process gives the central budget authority a position of strategic dominance over the finance ministers, it leads to fiscal discipline. This can limit the amendment power of parliament and can leave little room for changes in the budget during the execution process, which results in relatively small deficits and public debt.

Alesina and Perotti (1996) define this structure as "hierarchical" institutions, where strong prerogatives and powers are attributed to the treasury minister in the budget-preparation process within the executive branch. These institutions impose limits on the number and type of amendments that the legislature can propose, emphasizing a "top-bottom" approach. On the other hand, they define "collegial" institutions as structures that give more power to all the agents involved in the budgetary process. Other studies follow von Hagen (1992) and argue that more hierarchical budget procedures lead to greater fiscal discipline (Alesina and Perotti 1999).

Although a number of studies focus on different aspects of budget institutions, there have been a limited number of studies that investigate the relationship between fiscal performance and performance-based budgeting as a budget institution (Michael and Bates 2003). As far as I know, there have also been a limited number of studies about the relationship between performancebased budgeting procedures and fiscal performance.

For instance, Crain and O'Roark (2004) investigate the relationship between fiscal performance and performance-based budgeting system in the American States. According to their results, using panel performance-based budgeting helps states to reduce spending per capita by at least two percentage points. They measure performance-based budgeting by whether a state government has a performance-based budgeting process or not. However, they do not consider the extent of the performance information used in the performance-based-budget process.

More recently, Kwon (2017) divides the performance-based budgeting process into four steps and then he investigates the relationship between each step and the aggregate government debt and 
economic growth rates. He suggests that just having many performance targets or managing performance-based budgeting in corrupt environments does not guarantee fiscal discipline or efficiency. Know (2017) results suggest that performance-based budgeting has no direct impact on either aggregate fiscal discipline or economic growth. However, it has an impact on them when performance targets are linked to budget negotiation or to accountability and when the corruption level is low enough. Having many performance targets or managing performance-based budgeting in corrupt environments does not guarantee fiscal discipline. Besides these studies, other studies such as Aristovnik and Seljak (2009) discuss the link between performance information and the budgetary process in a country case. They argue that studies and crosscountry case comprehensions would be interesting topics to understand the relationship between fiscal performance and performance-based budgeting for further research.

However, studies do not consider how performance-based budgeting affects government deficit when countries don't have any budgetary consequences if targets are not met. This study contributes the literature not only by focusing on whether performance-based budgeting affects government deficit and performance information but also by investigating the relationship between the features of performance-based budgeting framework, especially when there are no budgetary consequences if targets are not met by using cross-country data.

\section{The Empirical Strategy}

As mentioned in the literature, there are two sets of explanatory variables. The first one is about the macroeconomic situation of countries which has some impact on budget deficit such as gross domestic product, inflation and unemployment rate (Saleh and Harvie 2005). The second set of explanatory variables is about the political and institutional determinants of budget deficit such as minority of government and budget institution (Hallerberg and Von Hagen 1997). As a dependent variable, studies generally use the budget deficit as an indicator of the fiscal performance while investigating the relationship between fiscal performance and its determinants (Gleich 2003; von Hagen and Harden 1995). Consistent with the literature mentioned above, I will use the following Equation 1 to estimate the relationship between budget deficit and budget institution.

$$
\text { deficit }_{i, t}=\propto_{i, t}+\beta_{1} \text { macroeconomic }_{i, t}+\beta_{2} \text { institutional }_{i, t}+u_{i}+\epsilon_{i, t}
$$

According to the literature above, the deficit is the general government deficit. I use the annual percentage growth rate of GDP (GDPGR), the unemployment rate (unemployment), the annual growth rate of inflation (inflation), the expenses of the government as a percentage of gross domestic product (expense), the net barter terms of trade index (trade) as macroeconomic variables. I use the performance-based budget index (PB) as an institutional variable. $u \_i$ is the unobserved country-specific effects, and $\epsilon_{-}(\mathrm{i}, \mathrm{t})$ is the error term. The subscripts $\mathrm{i}$ and $\mathrm{t}$ represent the country and time period, respectively. Thus, Equation 1.1 can be written as follows.

$$
\begin{aligned}
\text { deficit }_{i, t}= & \alpha_{i, t} \\
& +\beta_{1} \text { GDPGR }_{i, t}+\beta_{2} \text { unemployment }_{i, t}+\beta_{4} \text { inflation }_{i, t}+\beta_{5} \text { trade }_{i, t}+\beta_{6} \text { expense }_{i, t} \\
& +\beta_{7} P B_{i, t}+u_{i}+\epsilon_{i, t}
\end{aligned}
$$

An Alternative Empirical Strategy: A two-step regression approach 
To investigate the trade-off between PB and economic performance, I use the budget-related index. The index which will be introduced in the next section varies substantially across countries. However, it has little time variation. This situation only lets us apply the cross-country regressions which don't exploit the variation along the time dimension and, therefore, don't use all available information for the estimation. In order to deal with this problem, I divide the estimation into two steps by following Alesina et al. (1999) two-step-regression approach.

In the first step, I exclude the PB related variables which come from 2016 OECD Performance Budgeting Survey (without time variation) and estimate the coefficients for the rest of the explanatory variables which do vary over time, using a fixed effects regression.

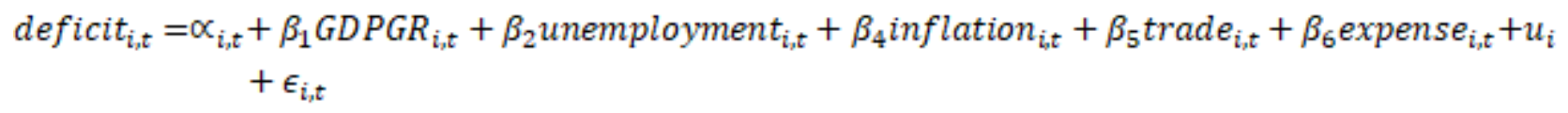

In the second step, after I calculate the estimated fixed effects from the panel regression model in Equation 2, I employ the hierarchical regression to analyse the relationship between calculated fixed effects and PB index and its sub_indexes. I construct the following equation,

\section{$F E=\propto+\beta_{1}$ institutional_index $+\epsilon$}

where FE refers to fixed effects from the panel regression model, institutional index is measured by $P B$ index which refers to the performance budgeting index, target which shows whether the government sets performance targets or not, negotiations which shows whether the government uses operations data and performance information in the budget negotiations or not and consequence which shows whether there are budgetary consequences if targets are not met.

\section{Data}

Empirical evidence on the relationship between budget institutions and fiscal performance, such as budget deficits, has relied on the construction of numerical indices. They give different information about key aspects of the budgetary process (Gollwitzer et al. 2010). In this respect, I use 2016 OECD Performance Budgeting Survey for measuring the performance budgeting index ( $P B$ _index) and sub-indexes. OECD (2017) divides the features of performance budgeting framework into three categories which are also in hierarchical order in terms of design, use and consequences: (I) whether the government sets performance targets, (II) whether the government uses operations data and performance info in budget negotiations or not and (III) whether there are budget consequences if targets are not met. 
Table 1: Features of performance budgeting framework

\begin{tabular}{|l|l|}
\hline \multirow{2}{*}{ Design } & Have a compulsory performance budgeting framework \\
\cline { 2 - 2 } & $\begin{array}{l}\text { Systematically set targets for all programmes } \\
\text { Use key national indicators }\end{array}$ \\
\hline \multirow{2}{*}{ Use } & $\begin{array}{l}\text { Use operations data and performance info in budget } \\
\text { negotiations }\end{array}$ \\
\hline \multirow{2}{*}{ Consequences } & Management responses if targets are not met \\
\cline { 2 - 2 } & Budgetary consequences if targets are not met \\
\hline
\end{tabular}

Source: OECD (2017)

My dataset comprises annual macroeconomic data on 33 countries, over the period $2011-2016$ from OECD National Accounts Statistics and World Development Indicators. I use the general government deficit (deficit) as the dependent variable. I use the annual percentage growth rate of GDP (GDPGR), the expenses of the government as a percentage of gross domestic product (expense), the unemployment rate (unemployment), the annual growth rate of inflation (inflation), net barter terms of trade index (trade) as the explanatory variables. I also use three sub-indexes which are shown in Table 1 as explanatory variables in the regression models. You can find descriptions and the sources of the variables and summary statistics of the variables in Table 3.

Table 2: Description of variables and data sources

\begin{tabular}{|c|c|c|}
\hline $\begin{array}{l}\text { Variable } \\
\text { Name }\end{array}$ & Description & Source \\
\hline deficit & $\begin{array}{l}\text { General government deficit, total } \\
\text { GDP\% }\end{array}$ & 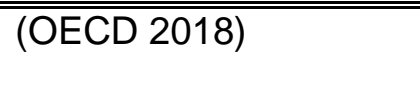 \\
\hline GDPGR & $\begin{array}{l}\text { The annual percentage growth rate } \\
\text { of GDP at market prices based on } \\
\text { constant local currency. }\end{array}$ & (The World Bank 2018) \\
\hline expense & $\begin{array}{l}\text { The expense is cash payments for } \\
\text { operating activities of the government } \\
\text { in providing goods and services (\% of } \\
\text { GDP) }\end{array}$ & (The World Bank 2018) \\
\hline unemployment & $\begin{array}{l}\text { The unemployment rate is the } \\
\text { number of unemployed people as a } \\
\text { percentage of the labour force. }\end{array}$ & (OECD 2018) \\
\hline inflation & $\begin{array}{l}\text { Inflation is measured in terms of the } \\
\text { annual growth rate ( } 2010 \text { base year ) }\end{array}$ & (OECD 2018) \\
\hline
\end{tabular}




\begin{tabular}{|c|c|c|}
\hline trade & $\begin{array}{l}\text { the percentage ratio of the export unit } \\
\text { value indexes to the import unit value } \\
\text { indexes }\end{array}$ & (The World Bank 2018) \\
\hline$P B$ index & $\begin{array}{l}\text { The } 2016 \text { OECD Performance } \\
\text { Budgeting Index shows the degree to } \\
\text { which performance budgeting } \\
\text { practices exist and are used at the } \\
\text { central level of government although } \\
\text { it does not measure how successful } \\
\text { they are in practice. }\end{array}$ & (OECD 2017) \\
\hline target & $\begin{array}{l}\text { Does your government set } \\
\text { performance targets? }\end{array}$ & (OECD 2017) \\
\hline negotiations & $\begin{array}{l}\text { Use operations data } \begin{array}{l}\text { and } \\
\text { performance info in budget } \\
\text { negotiations }\end{array} \\
\end{array}$ & (OECD 2017) \\
\hline consequences & $\begin{array}{l}\text { If performance targets are not met by } \\
\text { Line Ministries/Agencies, how likely } \\
\text { is it that any of the following are } \\
\text { triggered? }\end{array}$ & (OECD 2017) \\
\hline$F E$ & $\begin{array}{l}\text { Fixed effects calculated from the } \\
\text { panel data with fixed effect }\end{array}$ & Own calculation \\
\hline
\end{tabular}

Table 3: Summary statistics

\begin{tabular}{llllll}
\hline \hline Variable Name & Obs & Mean & Std. Dev. & Min & Max \\
\hline \hline deficit & 197 & -2.158048 & 3.734196 & -14.67861 & 13.83138 \\
GDPGR & 198 & 2.119472 & 2.807472 & -9.132494 & 25.55727 \\
expense & 198 & 33.95453 & 11.25578 & 2.166666 & 60.27922 \\
unemployment & 198 & 7.779384 & 4.048435 & 2.968629 & 27.46715 \\
inflation & 198 & 1.683522 & 1.821428 & -1.736046 & 8.89157 \\
trade & 198 & 102.837 & 27.14055 & 51.08044 & 221.8696 \\
PB_index & 33 & .3872727 & .1519924 & .05 & .61 \\
target & 33 & .3333333 & .4787136 & 0 & 1 \\
negotiations & 33 & .5454545 & .5056499 & 0 & 1 \\
consequences & 33 & .0909091 & .2919371 & 0 & 1 \\
FE & 33 & .0136861 & 7.485074 & -17.94117 & 11.49377 \\
\hline \hline
\end{tabular}




\section{$5 \quad$ Results}

Table 4 presents the estimated results of the linear regression equations which are shown above.

Column (0) presents the results of the Pearson correlation between variables. Column (I) presents the results of the OLS regression with means of the control variables from $2011-2016$ and performance budgeting index in 2016. (Equation 1.1)

Column II, III, IV, V and VI present the results of the two-step regression approach in Equation (2) and Equation (3). Column (III) presents the fixed effect panel data regression without performance budgeting index. As mentioned above, in the first stage, I only estimate panel data with fixed effects for calculating the fixed effects (FE) of countries. In the second stage, I use these fixed effects as a dependent variable and estimate Equation 3 and Equation 4. The dependent variable is the FE Column IV, Column V and Column VI. These models present the regression between FE and $P B \_$index, target, negotiations and consequence.

Table 4: Regression Results

\begin{tabular}{lccccccc}
\hline \hline Variable Name & $(0)$ & $(\mathrm{I})$ & $(\mathrm{II})$ & $(\mathrm{III})$ & $(\mathrm{IV})$ & $(\mathrm{V})$ & $(\mathrm{VI})$ \\
\hline \hline GDPGR & 0,09 & $-0,18$ & 0,40 & & & & \\
expense & $-0,22$ & $-0,006$ & $-0,65^{* * *}$ & & & & \\
unemployment & $-0,32$ & $-0,26$ & $-0,44$ & & & & \\
inflation & 0,38 & $0,72^{* *}$ & $-0,40^{* * *}$ & & & & \\
trade & 0,84 & $-0,10$ & 0,02 & & & & \\
PB_index & 0,02 & $-0,60$ & & 0,16 & & & \\
target & 0,20 & & & & $-2,1$ & $-2,3$ & $-1,85$ \\
negotiations & 0,23 & & & & & $-0,58$ & 0,94 \\
consequences & 0,17 & & & & & & $-8,58^{*}$ \\
constant & & 0,92 & $18^{* * *}$ & 0,20 & 0,5 & 1,1 & 6,28 \\
$N$ & 33 & 33 & 197 & 32 & 33 & 33 & 33 \\
Hausman & & & $67,42^{* * *}$ & & & & \\
$R^{2}$ & & 0,23 & 0,56 & 0,06 & 0,02 & 0,20 & 0,12 \\
F-prob & & 1,35 & $41,54^{* * *}$ & 0,16 & 0,46 & 0,74 & $0,28^{*}$
\end{tabular}

Note: P-values are significant at ${ }^{*} 0.10,{ }^{* *} 0.05$ and ${ }^{* * *} 0.01$. The dependent variable for (0), (I) and (III) is a deficit. The dependent variable for (IV), (V) and (VI) is FE. 
In the first stage, in the Panel Data with fixed effects in Column (III) ${ }^{1}$, there is a positive and statistically insignificant relationship between the GDPGR, trade and deficit (beta GDPGR $=0,40$, $\mathrm{p}=\mathrm{n}$.s.: beta trade $=0,02, \mathrm{p}=\mathrm{n} . \mathrm{s}$.). There is a negative and statistically insignificant relationship between unemployment and deficit (beta unemployment $=-0,44, p=n . s$.). Other coefficients, expense and inflation have a negative and statistically significant effect on the deficit (beta expense $=-0,65, \mathrm{p}<0.01$ : beta inflation $=-0,40, \mathrm{p}<0.01$ ).

According to results, in Table 4, there is a negative and statistically insignificant relationship between the target and FE (beta target $=-0.23, p=n . s$.). Yet, after adding negotiations as explanatory variable in Model IV, the effect of target and negotiations on FE is no longer significant (beta target $=-0.23, p=n . s$.: beta negotiations $=-0.58, p=n . s$.). After adding all three independent variables, even target and negotiations are still no longer significant (beta target =1.85, $p=n$. .: beta negotiations $=0.94, p=n . s$.). There is a negative and statistically significant relationship between FE and consequences (beta consequences $=-8,58, p<0.1$ ). This means that countries which have no consequences if targets are not met have more government deficit than countries which have consequences such as budget decreases, freezes and increases.

The results show that just using performance-based budgeting doesn't affect fiscal performance. However, the features and types of performance-based budgeting are important for fiscal performance. As a result, there should be some budgetary consequences if targets are not met.

\section{Conclusion}

My results suggest that performance-based budgeting does not have a direct impact on government deficit. The effect of it depends on how countries implement and use their features. According to the results, when performance targets are linked to budget consequences, performance-based budgeting has a negative effect on government deficit. More clearly, when a country allocates the resources directly and explicitly to the units of performance and link between performance and budget, the public deficit of the country decreases.

Although my empirical approach depends on limited data, empirical results (Kwon 2017), and the opinions of practitioners (Robinson 2016), as well as the country studies (Aristovnik and Seljak 2009) support my results. This study investigates the different features of performance-based budgeting framework by using OECD dataset. Focusing on different aspects and types of performance-based budgeting and cross-country comparison by adding different dataset would be better for further research.

\footnotetext{
${ }^{1}$ I tested for final specifications whether OLS, FE, or RE was to be preferred by using both theHausman specification test and the Breusch Pagan Lagrangian multiplier test. Breusch and Pagan Lagrangian multiplier test for random effects test result suggests that the pooled data is not proper for this model (chibar2 $(01)=206.68$ : Prob > chibar2 $=0.0000$ ). According to Hausman test results, individual effects $u_{i}$ are significantly correlated with the explanatory variables (67.42: Prob>chi2 $=0.0000)$. Therefore fixed effects model is used.
} 


\section{References}

Alesina, Alberto, Ricardo Hausmann, Rudolf Hommes, and Ernesto Stein. 1999. "Budget Institutions and Fiscal Performance in Latin America." Journal of Development Economics 59(2):253-73. Retrieved March 29, 2017

(http://www.sciencedirect.com/science/article/pii/S0304387899000127). https://doi.org/10.1016/S0304-3878(99)00012-7

Alesina, Alberto and Roberto Perotti. 1996. "Fiscal Discipline and the Budget Process." American Economic Review.

Alesina, Alberto and Roberto Perotti. 1999. "Budget Deficits and Budget Institutions." Pp. 13-36 in Fiscal Institutions and Fiscal Performance, edited by J. M. Poterba and J. von Hagen. Chicago, London: The University of Chicago Press.

Arif, Asma and Mujahid Hussain. 2018. "Economic, Political and Institutional Determinants of Budget Deficits Volatility: A Panel Data Analysis." International Journal of Economics \& Business Administration (IJEBA) 0(3):98-114. Retrieved (https://ideas.repec.org/a/ers/ijebaa/vviy2018i3p98-114.html).

Aristovnik, Aleksander and Janko Seljak. 2009. "Performance Budgeting: Selected International Experiences and Some Lessons for Slovenia." Journal of Economics 58(3):271-91. Retrieved (http://mpra.ub.uni-muenchen.de/15499/).

Crain, W. Mark and J. Brian O’Roark. 2004. “The Impact of Performance-Based Budgeting on State Fiscal Performance." Economics of Governance 5(2):167-86. Retrieved (http://link.springer.com/10.1007/s10101-003-0062-6). https://doi.org/10.1007/s10101-0030062-6

Curristine, Teresa. 2005. "Government Performance: Lessons and Challenges." OECD Journal on Budgeting 5(1). https://doi.org/10.1787/budget-v5-art6-en

Gleich, Holger. 2003. "Budget Institutions and Fiscal Performance in Central and Eastern European Countries." Retrieved (https://papers.ssrn.com/sol3/papers.cfm?abstract_id=387703).

Gollwitzer, Sophia et al. 2010. "Budget Institutions and Fiscal Performance in Low-Income Countries." IMF Working Papers 10(80):1. Retrieved (http://elibrary.imf.org/view/IMF001/10845-9781451982237/10845-9781451982237/108459781451982237.xml). https://doi.org/10.5089/9781451982237.001

von Hagen, Jurgen. 1992. "Budgeting Procedures and Fiscal Performance in the European Communities. Economic Papers 96, October 1992. II/453/92/-EN/Rev Budgeting Procedures and Fiscal Performance in the European Communities." Retrieved (http://aei.pitt.edu/37058/\#.W6SgXIW1ejQ.mendeley).

von Hagen, Jürgen and lan J. Harden. 1995. "Budget Processes and Commitment to Fiscal Discipline." European Economic Review 39(3-4):771-79. https://doi.org/10.1016/00142921(94)00084-D

Hallerberg, Mark and Jurgen Von Hagen. 1997. Electoral Institutions, Cabinet Negotiations, and Budget Deficits in the European Union. National Bureau of Economic Research. Retrieved (http://10.0.13.58/w6341). https://doi.org/10.3386/w6341

Ifere, Eugene Okoi and Okoiarikpo Benjamin Okoi. 2018. "Political Economy of Fiscal Deficits in a Democracy." EconomiA 19(1):12-23. Retrieved (https://www.sciencedirect.com/science/article/pii/S1517758017301017). https://doi.org/10.1016/j.econ.2017.10.002 
Kwon, Illoong. 2017. "Performance Budgeting: Effects on Government Debt and Economic Growth." Applied Economics Letters 1-5. Retrieved July 7, 2017

(https://www.tandfonline.com/doi/full/10.1080/13504851.2017.1324607).

Maltritz, Dominik and Sebastian Wüste. 2015. "Determinants of Budget Deficits in Europe: The Role and Relations of Fiscal Rules, Fiscal Councils, Creative Accounting and the Euro." Economic Modelling 48:222-36. Retrieved (http://www.sciencedirect.com/science/article/pii/S0264999314004672). https://doi.org/10.1016/j.econmod.2014.12.001

Michael, Bryane and Michael Bates. 2003. "Assessing International Fiscal and Monetary Transparency: The Role of Standards, Knowledge Management and Project Design." International Public Management Journal 6(2):95-116. Retrieved (http://www.scopus.com/inward/record.url?eid=2-s2.0-7244245723\&partnerlD=tZOtx3y1).

Moynihan, Donald and Ivor Beazley. 2016. Toward Next-Generation Performance Budgeting: Lessons from the Experiences of Seven Reforming Countries. The World Bank. Retrieved February 6, 2017 (http://elibrary.worldbank.org/doi/book/10.1596/978-1-4648-0954-5). https://doi.org/10.1596/978-1-4648-0954-5

OECD. 2005. Modernising Government: The Way Forward. Paris. Retrieved February 16, 2016 (http://www.keepeek.com/Digital-Asset-Management/oecd/governance/modernisinggovernment_9789264010505-en\#page59).

OECD. 2007. Performance Budgeting in OECD Countries.

OECD. 2017. "Performance Budgeting." in Government at a Glance 2017. Paris: OECD Publishing.

OECD. 2018. National Accounts at a Glance. Retrieved (https://www.oecdilibrary.org/economics/data/oecd-national-accounts-statistics/national-accounts-at-aglance_data-00369-en).

Raudla, Ringa. 2012. "The Use of Performance Information In Budgetary Decision-Making By Legislators: Is Estonia Any Different?" Public Administration 90(4):1000-1015. Retrieved (http://doi.wiley.com/10.1111/j.1467-9299.2012.02041.x).

Robinson, Marc. 2016. "Budget Reform before and after the Global Financial Crisis." OECD Journal on Budgeting 16(1):29-63. https://doi.org/10.1787/budget-16-5jlvc85w7nkf

Robinson, Marc and Jim Brumby. 2005. "Does Performance Budgeting Work? An Analytical Review of the Empirical Literature." IMF Working Papers 05(210):1. Retrieved (http://elibrary.imf.org/view/IMF001/01833-9781451862294/01833-9781451862294/018339781451862294.xml). https://doi.org/10.5089/9781451862294.001

Roubini, Nouriel. 1991. "Economic and Political Determinants of Budget Deficits in Developing Countries." Journal of International Money and Finance 10: S49-72. Retrieved (https://www.sciencedirect.com/science/article/pii/026156069190046M). https://doi.org/10.1016/0261-5606(91)90046-M

Roubini, Nouriel and Jeffrey D. Sachs. 1989. "Political and Economic Determinants of Budget Deficits in the Industrial Democracies." European Economic Review 33(5):903-33. Retrieved (https://www.sciencedirect.com/science/article/pii/0014292189900020). https://doi.org/10.1016/0014-2921(89)90002-0

Roubini, Nouriel, Jeffrey Sachs, Seppo Honkapohja, and Daniel Cohen. 1989. "Government Spending and Budget Deficits in the Industrial Countries." Economic Policy 4(8):100-132. Retrieved (http://www.jstor.org/stable/1344465). https://doi.org/10.2307/1344465 
Saleh, A. L. I. Salman and Charles Harvie. 2005. "THE BUDGET DEFICIT AND ECONOMIC PERFORMANCE: A SURVEY." The Singapore Economic Review 50(02):211-43. Retrieved (https://doi.org/10.1142/S0217590805001986). https://doi.org/10.1142/S0217590805001986

Shick, Allen. 2007. "Performance Budgeting and Accrual Budgeting: Decision Rules or Analytic Tools?" OECD Journal on Budgeting 7(2). https://doi.org/10.1787/budget-v7-art11-en

Swamy, Vighneswara. 2015. Government Debt and Its Macroeconomic Determinants \{ An Empirical Investigation. https://doi.org/10.2139/ssrn.2601875

The World Bank. 2018. "World Development Indicators | Data." Retrieved (https://data.worldbank.org/products/wdi).

Woo, Jaejoon. 2003. "Economic, Political, and Institutional Determinants of Public Deficits." Journal of Public Economics 87(3-4):387-426. Retrieved (https://www.sciencedirect.com/science/article/abs/pii/S0047272701001438). https://doi.org/10.1016/S0047-2727(01)00143-8 